\title{
Degrees of Culpability: Suicide Verdicts, Mercy, and the Jury in Medieval England
}

\author{
Sara M. Butler \\ Loyola University New Orleans \\ New Orleans, Louisiana
}

Sunday, January 23, 1390 was a day that Ralph Peioun of Wotton (Lincs.) and his wife most likely never forgot. On this day, their one-year-old son, Richard, presumably curious and headstrong like most young toddlers his age, made an unfortunate choice of playthings when he picked up a pair of shears and wounded himself in the throat, a fatal injury leading to his death later that same day. In many ways, Richard's behavior was not unlike that of many other children his age in medieval England. The coroners' rolls are replete with entry upon entry of similar incidents of children whose deaths seem to be the products of negligent supervision at a time when some mothers were overwhelmed trying to balance the wearisome demands of work and childcare: cradles being overturned by chickens into hearth fires, maulings by the family pig, children falling into wells or cauldrons of boiling water, dangerous games that led to unexpected (and unlucky) outcomes. In the midst of these gruesome and appalling cases of death by misadventure, a one-year-old boy dying because of knife-play is nothing extraordinary, scarcely worthy of mention. What is unusual about his death is the final decision made by a trial jury upon his case and written boldly in the marginalia of this Lincolnshire coroner's roll: "suicide" [felonia de se]. ${ }^{1}$

It is difficult to imagine that any group of twelve "good men and true" might seriously believe that a one-year-old boy had set out deliberately and feloniously to kill himself with a pair of shears. Moreover, their decision in this matter is in direct contravention of the very principles behind an indictment of felony in cases of homicide: an infant lacks criminal intent (mens rea) and is thus legally incompetent. In the words of the thirteenthcentury legal treatise traditionally attributed to Henry de Bracton, minors, like the insane and the mentally deficient, are "without sense and reason and can no more commit an injuria or a felony than a brute animal, since they are not far removed from brutes." 2 The unusual and severe decision 
of the jury in this case, then, is both remarkable and puzzling. While it is possible to blame this incongruity on scribal error, the seriousness of such a verdict and its accompanying consequences would suggest that court scribes were probably determined to err on the side of caution when employing the phrase. If the marginalia accurately reflects the trial jury's verdict, given the evidence, two explanations seem plausible. First, the jury may have believed Richard's death was a poorly disguised homicide. Even with sufficient evidence, however, accusations of infanticide had little hope of conviction in a king's court. ${ }^{3}$ In the absence of evidence, then, a verdict of felonia de se might have achieved the same level of social embarrassment and communal ostracism. Second, and perhaps more probable, Richard's death may have resulted from parental negligence. A ruling of suicide, then, would have penalized the toddler's delinquent parents, perhaps not financially but with respect to their reputation and standing in the community. ${ }^{4}$ While a verdict of misadventure might have swept this case under the rug of obscurity, the jury's decision to declare this infant's death a suicide, and thus prohibit burial in consecrated ground, must have made the whole community sit up and take notice. A declaration of suicide subjected a family to "trauma and social embarrassment" arising from barbaric burial rituals that were "both physically brutal and spiritually comfortless." 5 What stronger way to impress on the parents of young children that knives are not toys, and that children require supervision? Here, it is important to note that this is not the first suggestion that the medieval English were apprehensive about careless parents. R. H. Helmholz's seminal 1972 study of infanticide in the church courts observes that the English church disciplined parents responsible for the deaths of children through negligence, particularly in cases of overlaying. ${ }^{6}$ Barbara Hanawalt's more recent study of communal child-rearing presents a compelling argument for the existence of "a narrative tradition of teaching and enforcing nurturing, an official policy of doing so, and a deeply embedded moral value placed on it." 7 Thus, the decision of the jury may well reflect these communal values.

Unfortunately, the record of Richard's death itself offers no indication of why the trial jury might have thought Richard's death called for such a curious approach. If the verdict was indeed intended to teach a lesson in parental supervision, it is likely that this was not the first time his parents found their conduct at odds with local opinion. The decision to declare Richard's death a suicide, however, had important spiritual ramifications that must have posed difficulties for the jurors in this case. As Rosemary Horrox has remarked, medieval Englishmen and women thought suicide 
was "the most extreme form of the bad death." It was "the most profound of sins - the ultimate rejection of divine grace - and the overwhelming sinfulness of suicide eclipsed any perception of it as a crime." ${ }^{8}$ Christian doctrine and popular folklore combined to reinforce the notion that suicides must be judged harshly. In a marked departure from the classical tradition where suicide was legal and often romanticized, since Augustine the medieval church held up the presumed suicide of Judas as "the archetype of a shameful, damnable death, not so much for the act itself as for the despair that prompted it." Christian belief cultivated the idea that despair was an unpardonable sin because it signified a loss of faith, and thus a rejection of Christ. ${ }^{9}$ Popular folklore, on the other hand, filled Englishmen and women with apprehensions of the dead returning to harass the living. Jean-Claude Schmitt reminds us of the strong belief held by medieval people that those who died without a proper funeral and the prescribed mourning rituals "rebelled against the will of the living to forget," and instead, "invaded their dreams, and haunted their homes."10 The gravity of these dual concerns must have weighed heavily on the hearts and shoulders of jurors confronted with self-killings. In the case of Richard Peioun, it is difficult to understand exactly why jurors believed that it was more important to send a message to the parents, than to pay heed to these serious spiritual considerations, including a proper burial for the child. It would seem that jurors viewed this incident as an opportunity to make a public statement about parental negligence, and believed that the benefits of their decision as a deterrent to other parents outweighed the spiritual damage.

The verdict in the death of Richard Peioun reveals that a medieval jury's declaration of suicide masks a much more complex decision-making process than historians have previously imagined. In many ways, this finding should come as no surprise. While historians of the English common law have traditionally recognized that medieval juries played an essential role in mitigating the severity of the law, research by Thomas Green and John Bellamy among others indicates that tampering with verdicts by all forms of juries ran much deeper than merely a reluctance to sentence individuals to death. ${ }^{11}$ Instead, jurors acted in accordance with a code of communal ethics. When the jury chose to acquit an accused felon, it was because the legal process had already fulfilled its need, compelling the defendant to behavioral reform or a private settlement; when the jury chose to convict, it was because the defendant's behavior had exceeded unofficial and official controls, and reform did not seem likely. In the system of criminal law, then, the jury was often in command. Bearing this in mind, jury nullification must have had 
a similar impact on verdicts of felonious self-killing. The declaration of suicide was understandably an important ethical concern both religiously and economically, because the king claimed the right to confiscate for a year and a day the lands and chattels of those declared guilty of self-killing. The only exemptions were supposed to be those cases where the defendant was non compos mentis, and thus not responsible for his or her actions. In the eyes of a jury, the declaration of suicide had the unenviable power to condemn the dead to a tortuous afterlife in purgatory, while at the same time sentencing the family to probable destitution..$^{12}$ Knowing the financial burden that such a family might become to their community, jury members may have been reluctant to make that choice. With so many lives in the balance, Hanawalt's conclusion that "community feeling would [have been] with the surviving family" has won much support from historians. ${ }^{13}$

The significance of local experience as an influence on legal judgments has been the central focus of recent historians of medieval suicide. Nonetheless, a wide diversity of conclusions has been drawn about jury behavior where suicide is concerned. Michael MacDonald and Terence R. Murphy, for example, have sided with Hanawalt, arguing that medieval juries overlooked the spiritual ramifications and regularly employed non compos mentis pleas to excuse the defendant's actions rather than impoverish the victim's family. ${ }^{14}$ Alexander Murray proposes a more balanced vision of the medieval courts. Compassion was still a crucial element; however, he sees that manipulation of court verdicts was related intimately to gender: juries more frequently excused women of the crime because "female suicide was just too horrible to think about."15 Not all historians have adopted such a sympathetic view of the medieval jury. More recently, Gwen Seabourne and Alice Seabourne have proposed that historians have only "imagined" that suicide was treated with such leniency by medieval juries because it "is not now generally regarded as a matter which should be the subject of punishment." They contend that even mental instability did not necessarily deliver a perpetrator (and his or her family) from the rigors of a declaration of suicide. ${ }^{16}$

The case of Richard Peioun challenges the notion of the ubiquitous mercy of medieval jurors. Rather, it demonstrates that jurors were not always inclined to mercy and, in fact, might manipulate trial verdicts in creative ways to impose their own sets of beliefs. This study, based on an exhaustive search of coroners' rolls, alongside eyre and assize rolls, aims to provide a clearer understanding of the value system embraced by medieval English 
juries in cases of self-killing. Accordingly, this grouping of cases is capable of providing a much expanded vision of medieval perceptions not only of suicide, but also of insanity and accountability at law.

\section{The records}

To date, coroners' rolls have not been the primary focus of historians of suicide, yet these rolls present themselves as the ideal records for a study of attitudes toward medieval suicide. They document verdicts given by the coroners' inquest jury in cases of violent or unexpected death. As is the case today, it was the responsibility of the medieval coroner and his jury to determine the cause of death. In the course of an inquest, the coroner assembled a jury of neighbors and witnesses who combined efforts to determine a preliminary judgment. Their findings drew on the presentment of the first finder, a physical examination of the body, and local knowledge of what had transpired. This initial verdict was then recorded in rolls by the coroner's scribe and retained by the coroner, who was expected to produce these rolls at the next eyre or assize session to be checked against the grand jury's presentments and therewith submitted to the trial jury for a final verdict. ${ }^{17}$ The coroners', eyre and assize rolls thus represent two halves of the same process, complementing each other's strengths and compensating for each other's weaknesses. Where the eyre and assize rolls provide far more numerous examples of cases of suicide due to a much greater manuscript survival rate, the coroners' rolls offer superior detail and a more familiar relationship with the deceased. Together, an analysis of these records affords valuable insight into the role played by medieval juries in determining verdicts of suicide.

This study explores a broad range of cases from across England from the thirteenth to the very early sixteenth century. Because a relatively small corpus of coroners' rolls has survived the Middle Ages, I have examined all coroners' rolls housed at the Public Record Office in London, as well as all printed coroners' rolls. These records provide insight primarily into fourteenth-century cases, although some later coroners' rolls are extant. Records of eyre or assize exist in such high numbers that a similar approach was simply not feasible. For two counties, Essex (representing the south of England) and York (representing the north), I have examined all surviving eyre and assize rolls. For the remaining counties, I have examined roughly two eyre or assize rolls from each county, selected primarily for the length and quality of these particular rolls, in addition to all printed eyres and 
assizes. ${ }^{18}$ These records are particularly strong for the thirteenth century. The result is a grouping of 718 cases of self-killing from across England, concentrated primarily in the thirteenth and fourteenth centuries. ${ }^{19}$

While the geographical spread of suicides is not my focus here, breaking down this group of 718 cases of suicide by county suggests that the specter of suicide was a much greater concern in some areas than it was in others (see table 1). ${ }^{20}$ It is not hard to imagine that regional conditions, for example constant warfare in the north with Scotland or pronounced poverty on the periphery, may have exacerbated living conditions to the point where suicide presented itself to Englishmen and women as a viable alternative to an untenable existence. It is quite possible, however, that these figures do not necessarily represent actual rates of suicide; rather, they may well indicate that some regions of England possessed a heightened sense of concern about self-killings and were thus more vigilant in both the reporting and trying of cases of suicide.

From this grouping of 718 cases, it is immediately apparent that certain scholarly assertions about medieval verdicts of suicide do not stand up to close scrutiny. MacDonald and Murphy's declaration that “juries very seldom returned verdicts of felonia de se prior to 1500" lacks support in these records. ${ }^{21}$ The records describe the vast majority of cases, 565 out of 718 , or roughly 79 percent, as felonious suicides in either the marginalia or the narrative or both. ${ }^{22}$ Such a high figure makes the argument that "the law of self-murder was only enforced when it was unavoidable to do so" difficult to sustain. ${ }^{23}$ Moreover, in spite of Murray's assertion that medieval society was reluctant to recognize the possibility of female suicide, in fact, women committed suicide at a much higher rate than any other type of felony. Of the 718 cases of suicide appearing in the coroners' and eyre rolls, 464 were committed by men, 253 by women, indicating that women carried out roughly 35 percent of suicides. ${ }^{24}$ In contrast, Barbara Hanawalt has argued that grand juries rarely accused women of felonies; they appear as suspects in only 10 percent of the felonies considered in her study. ${ }^{25}$ Her findings suggest that although female suicides might have been in the minority, they were a very visible and meaningful minority. Moreover, while Murray correctly notes that female self-killers are less frequently described as felons in these records, medieval juries still overwhelmingly described female self-killers as such. The term was employed in 74 percent of female self-killings, while 81 percent of the 464 male self-killings were described in this manner. With these numbers, Murray's assertion, cited above, that "female suicide was just too horrible to think about" simply does not reflect reality. 
Table 1.

Reported self-killings by county.

\begin{tabular}{|c|c|}
\hline County & Number of Reported Self-killings \\
\hline Bedford & 12 \\
\hline Berkshire & 9 \\
\hline Buckingham & 4 \\
\hline Cambridge & 29 \\
\hline Cornwall & 12 \\
\hline Cumberland & 5 \\
\hline Derby & 13 \\
\hline Devon & 14 \\
\hline Dorset & 11 \\
\hline Durham & 3 \\
\hline Essex & 30 \\
\hline Gloucester & 16 \\
\hline Hampshire & 18 \\
\hline Hereford & 7 \\
\hline Hertford & 4 \\
\hline Huntingdon & 9 \\
\hline Kent & 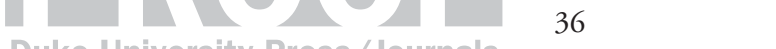 \\
\hline Lancashire & Duke University Press/Journals \\
\hline Leicester & 17 \\
\hline Lincoln & 43 \\
\hline London & 13 \\
\hline Middlesex & 10 \\
\hline Norfolk & 30 \\
\hline Northamptonshire & 43 \\
\hline Northumberland & 18 \\
\hline Nottingham & 36 \\
\hline Oxford & 18 \\
\hline Rutland & 2 \\
\hline Shropshire & 25 \\
\hline Somerset & 12 \\
\hline Stafford & 12 \\
\hline Suffolk & 13 \\
\hline Surrey & 4 \\
\hline Sussex & 6 \\
\hline Warrick & 10 \\
\hline Westmorland & 7 \\
\hline Wiltshire & 15 \\
\hline Worcester & 4 \\
\hline York & 135 \\
\hline Total & 718 \\
\hline
\end{tabular}


That juries were inclined to issue verdicts of felony, even in the case of female suicides, bears witness to the Seabournes' contention that modern perceptions have clouded our thinking about medieval suicide. While lenience for the family may seem the most compassionate and humane response to a suicide, to a medieval juror, an overriding sense of sympathy may have seemed luxurious when faced with such grave matters as mortal sin and ghostly visitations.

\section{Mental defect: An exception to the rule?}

Despite the manifold judgments of felonious suicide, not all self-killings were deemed suicides. Bracton's principle that the non compos mentis be exempt from this ruling was widely known; canon law reinforced this perspective. By the thirteenth century, canonists were in firm agreement that "a madman could not be held responsible for his deeds because (1) he did not know what he did; (2) he was impelled or forced by some inexplicable necessity; or (3) he was not capable of reason - that is, he was not in charge of himself because he lacked the faculty of deliberation.” As H. C. Erik Midelfort has noted, "Madness wiped out freedom and thus all imputation of sin."26 Regardless of these twin pillars championing the rights of the mentally unstable, jurors nevertheless had some difficulty in determining just who was legally competent and thus responsible for his or her actions. ${ }^{27}$ Juries employed a wide variety of descriptions of mental imbalance to explain self-killings (fury, frenzy, dementia, lunacy, madness, diabolical temptation, acute fever, etc.). Of the 718 cases of self-killing, juries recorded evidence of mental instability in 105 cases (or roughly 15 percent). Such a significant figure implies that medieval Englishmen and women recognized that mental instability was a common motivation for suicide. An eyre roll from Hereford in 1292 offers a visual association of this bond: although Thomas Chese of Cotton, who slit his throat in his home in Eccleswell, is nowhere described as a madman or mentally deficient in any way, in the margins of the record of his death is the drawing of a fool (see fig. 1). Although very tentative, such a casual allusion suggests the possibility that implicit in each case of suicide is the notion that some mental defect was at play; juries may even have believed that a notation in the records was necessary only in cases of extreme lunacy. At the very least, it underlines the notion that Englishmen and women recognized a tangible connection between mental defects and self-killings.

The records themselves adopt a benevolent tone in recounting many cases of mad self-killing, exhibiting sympathy for the self-killer, as well as 


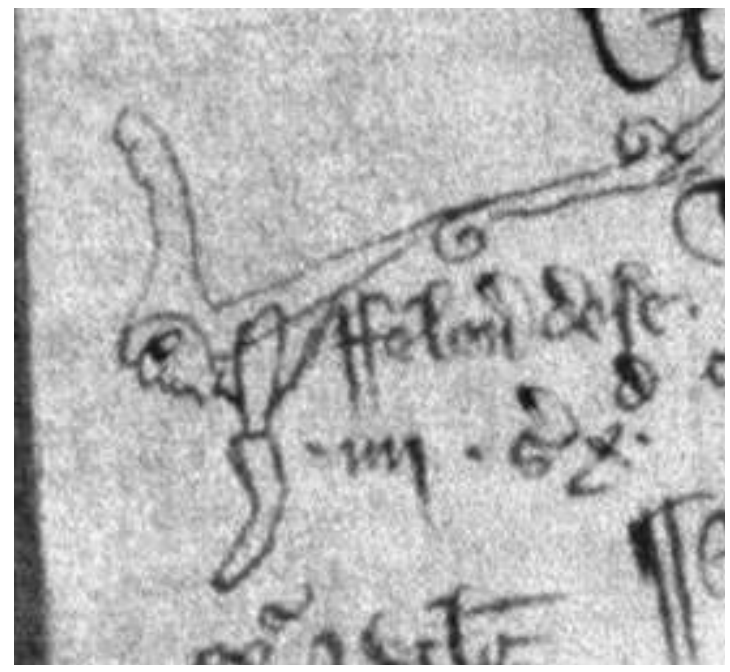

Figure 1.

Image of a fool in the

margins of an eyre roll

record of Thomas Chese of

Cotton's death. Courtesy of

the Queen and the National

Archives, London, TNA

JUST 1/302, m. 75d

(Hereford).

an awareness that insanity should render an individual legally incompetent. For example, an eyre roll from the year 1286 notes that when Thomas son of Henry Robekyn of Brandon, Norfolk, suffering from frenzy, severed his left foot and hand with an axe in the home of his father, he returned to his senses immediately after the act and even received last rites before he died. The record goes on to state that because the act had been committed while he was out of his mind, it was not a felony but an accident. ${ }^{28}$ Similarly, an assize roll from London describes a woman named only as Joan as having been mad when she drowned herself, and that "she was in such a state that she could not forfeit [her] chattels because of her illness." The sheriff subsequently ordered that the "chattels should be given in alms for the soul of the same Joan, and the king would concern himself no more with those chattels." 29 These cases, while not common, nonetheless were not exceptional. A small grouping of cases featuring similar phraseology has survived from the period, illustrating that medieval Englishmen and women understood the non compos mentis clause, and sometimes applied it out of compassion.

Irrespective of Bracton's concession to "the deranged, the delirious and the mentally retarded," in practice, mental instability was not a universal justification for exemption from a declaration of felony, and thus the confiscation of all goods and chattels. ${ }^{30}$ In fact, it was not even a very reliable defense in the event of a self-killing. Of the 105 cases described as selfmurder in the throes of insanity, scribes recorded 42 (or 40 percent) as felonious in the margins and/or the narrative. Moreover, in many of these cases the records themselves do not even hint that indicting juries put forward a 
non compos mentis plea for consideration. For example, in the year 1345 when Joan Papys of Coventry drowned herself, the coroner's roll reports that she did so not only feloniously [felonice] and voluntarily [voluntarie], but also while out of her mind and in a fury [extra memoriam in furore suo]. The roll also specifically notes that the full penalty of the law was imposed: Joan was buried outside church property [extra ecclesiastica seppeliatur], meaning in unconsecrated ground. ${ }^{31}$ Similarly, a roll from the Buckinghamshire eyre of 1241 recounts how when Humphrey the leper hanged himself, he did so out of the frenzy of sickness [quod per furore infirmitatis]; the jury proceeded to judge his act to be "felonia de se ipso." 32 These two cases, highlighting the juxtaposition of such incompatible descriptions, are not exceptional. Jurors seem to have been very comfortable portraying a self-killing simultaneously as the outcome of both an insane and a criminal mind.

Historians have proposed a number of hypotheses to explain why madness did not summarily exculpate a self-killing. In an examination of a late-thirteenth-century suicide, Anne and Edwin DeWindt have proposed that although justices recognized that victims of insanity should not be held responsible for their actions, they "ignored the more normal procedure in such a case and ruled felonia de se rather than misadventure," because such a ruling "brought greater financial benefit to the crown." 33 This possibility, however unsavory, should not be dismissed out of hand. The profits of justice were a powerful motivator in medieval England and often account for the kind of justice meted out in its courts: a coroner or royal justice anxious to fill the king's coffers may have abused his position to influence jurors toward a verdict of felony. Many of those suicides described as insane and yet declared felonious were relatively affluent individuals. For example, when Thomas son of Hutred of Hawkhill, languishing with a disease referred to in a thirteenth-century eyre roll as angustia "anguish", fell into frenzy, drew his knife and stabbed himself in the chest, he left behind chattels worth 101 shillings, 10 pence. ${ }^{34}$ While Thomas represents the upper end of the spectrum where wealth is concerned, at least eleven other suicides reported as being mentally unstable had goods worth more than 20 shillings at their death. Juries handed down judgments of felonia de se in all twelve of these cases. Nevertheless, while the king's financial wellbeing may have inclined some jurors toward a verdict of felony, the profits of justice do not account for all or even most of those cases that seemingly should have been declared non compos mentis. Many of these alleged madmen and women had few or no chattels at all, and yet their intent was still found to be criminal. 35

Gwen Seabourne and Alice Seabourne maintain that the expla- 
nation can be found instead in a "consistent, or fairly consistent, working distinction between different degrees of mental disturbance, in terms of the perceived ability of the deceased to understand the consequences of action, and to form a fixed intention" employed by members of the jury in determining their verdicts. Seabourne and Seabourne argue that while the simplicity of the terminology employed by jurors might "give the appearance of inconsistency," in fact, these terms mask a complex system in which "[ $t]$ he 'frenzied' might be exculpated" while "lunacy never seems to have exculpated suicide." 36 The legal treatises of the period offer some support for the contention of a more complex understanding of mental deficiency. Bracton maintained a distinction between the simple-minded (idiotus) and the insane (furiosus). He was also cautious to note that even those madmen who enjoyed lucid intervals should be exempt from punishment, providing the act was not committed while lucid. ${ }^{37}$ Britton (ca. 1290) and Fleta (ca. 1271-1307), on the other hand, more concerned with the rights of the mentally deficient to inherit property, were careful to acknowledge a difference between those "born senseless" and those who "become senseless" later in life (the former might inherit, but not the latter). ${ }^{38}$ This distinction is made more clear in The Mirror of Justices (ca, 1290s), which highlights the role played by sin in mental defect. Those who were born mentally deficient live without sin; those who become feeble-minded "share in the moral taint of sin." 39 Medieval physicians also distinguished different forms of mental disease, but in much different ways. They drew a firm line between melancholia, depression characterized by dispirited and torpid behavior, and mania, "a condition marked by excess and uncontrollability." Both melancholia and mania, Roy Porter notes, might be the product of faulty diet or an excess of blood, and thus physicians regularly prescribed both bloodletting and a change of diet to rebalance the humors..$^{40}$ How well jurors were acquainted with any of this legal or medical knowledge, however, remains a mystery. Some communities must have had experience with formal trials to determine an individual's mental deficiency. As Wendy Turner notes, a legal process existed by which a person might receive the label "idiot" or "lunatic," the obvious benefits being the appointment of a royal guardian to ensure the proper devise of an inheritance. This process was effectively a trial involving a jury and witnesses, in which royal justices asked questions about the nature of the individual's feeble-mindedness. ${ }^{41}$ Such a process should have assisted in the dissemination of the legal terminology and perceptions of mental deficiency; and yet, as Turner's study indicates, this was not a frequent occurrence. 42 
The records themselves suggest that jurors did not adhere to the legal or medical perceptions of mental instability. Of the 42 cases of felonious suicide reportedly motivated by mental defect, there does not seem to be any recognizable pattern of clemency. The frenzied were most often excused of the crime (only 8 out of 27 had verdicts of felonia de se returned), and yet the term frenzy (frenesy/i, frenesium) was employed far more often than any other and seems, in large part, to have been the stock phrase for madness. Other popular expressions point to a similar inconsistency in terms of declarations of felony: fury (furiosus, 7 out of 16), insanity (insania, 4 out of 11), dementia (demens, amens, 2 out of 6), and lunacy (lunaticus, 2 out of 4). It is noteworthy that the term melancholia does not appear even once in the records. A slightly more reliable index lay with suicides incited by the devil or evil spirits: juries declared half (7 out of 14) of these felonious. It is striking, however, that even those cases where the individual was recognized widely as a madman might also be awarded a verdict of felony. Indicting jurors described both Robert "le Wode" or Adeline "Woderone" (whose very names proclaim their madness, wode being the Middle English term for "mad") as having taken their own lives feloniously. ${ }^{43}$ What is clear from these findings is that at least some jurors were capable of employing the appropriate legal terminology to indicate an absence of accountability. Seven out of 105 suicides were described as being non compos mentis, while at least one other, a William son of Thomas of Below of Scalingburgh (Yorks.), was described as being incapable of discerning between right and wrong [non habuit discretionem boni nec mali], meeting the qualifications of what would later be referred to as the wild beast test. ${ }^{44}$ Even so, grand jurors noted that at least two of these individuals met their deaths feloniously, once again leaving the impression that jurors determined exemption from the non compos mentis clause in a much different way than Bracton or anyone else has suggested.

The absence of findings of legal incompetence in some cases is equally telling. For example, when John Walistheman of Wales took his life by slicing off his penis and testicles [abscidit veretrum suum et testiculos suos propros] and then subsequently bleeding to death, the modern reader of this case, well-versed in Freud and his various complexes, might well find it hard to ignore the possibility of a sexual-psychological motivation to this crime. Granted, while the record of the Welshman's case does not proclaim it a felonious self-killing, neither does it insinuate that he was a raving madman whose legal competence was questionable. ${ }^{45}$ Similarly, a Wiltshire eyre roll from the year 1249 reports that Simon of Cheldrincton struck himself in 
the belly, plucked out his intestines, and with his own hands tore them apart and speedily died. Rarely do the coroners', eyre, or assize rolls record suicides of this dramatic nature. Such a frenzied method of self-killing hardly seems the act of a sound mind. Yet, his indicting jury declared his actions felonious. ${ }^{46}$ The preliminary conclusion drawn by the coroners' inquest jury in both these cases suggests that Englishmen may have employed a complex understanding of insanity far different from what we might expect today.

Nor do jurors appear to have been consistent when resorting to claims of insanity. For example, a Hampshire coroner's roll notes the 1369 case of Maud wife of William Chantour, who is described as having been out of her mind [demens] when she killed John son of Richard Rugeman, aged three and more, also a resident of North Wallop. 47 Because of her mental instability, the court found Maud exempt from any punishment for these actions. Not long afterwards, however, when she took her own life by hanging herself in her husband's barn, her state of mind does not even figure in the report by the inquest jury. Instead, it declared merely that she was a felon, and thus responsible for her actions. ${ }^{48}$ Without any further corroborating evidence to flesh out the jury's decision in this case, it seems possible to interpret these two judgments as a statement that compassion only extended so far. While Maud's state of mind may have been sufficient to absolve her first lapse into criminality, it was not enough to pardon the taking of her own life. Here, a judgment of felonia de se may have had a double meaning. Much like the verdict handed down in young Richard Peioun's case, the jury may have intended to offer a pointed message to Maud's guardians: while the dereliction of their supervisory duties might be overlooked once, repeated neglect was not acceptable. Another possible explanation for Maud's verdict is that it reflects a popular sense of criminality carried over from the time of the Anglo-Saxons. As Georges Minois notes, the Anglo-Saxon penitentials of the eighth and ninth centuries make it clear that "only the insane or the possessed are excused from punishment for suicide, and then only if they had lived honorably before falling into the clutches of the devil." 49 Although Bracton and other treatise writers of the period make no such distinction in their discussion of legal competence, the value of an unsullied reputation to the verdicts of later medieval jurors is hard to deny. Thomas Green has argued that good standing in a community was enough to turn jurors away from a verdict of homicide and might even have led them to excuse a crime as self-defense or misadventure. ${ }^{50}$ The power of reputation in medieval England was such that, in his history of crime in medieval Europe, Trevor Dean notes confidently that, in England, juries' verdicts "were based not on 
evidence or testimony, but on assertion and reputation." 51 With most verdicts of suicide, the records prevent us from discovering how pivotal a role honor and character played. If Maud's murderous background hardened the hearts of inquest jurors, it is possible that reputation explains felonious verdicts in many other cases of insane self-killing. Certainly, Maud's case demonstrates that the application of the non compos mentis plea by a medieval jury might be very subjective and difficult to interpret.

At the very least, these cases suggest that the language of insanity, when used in cases of self-killing, was contextual. At times, jurors used the non compos mentis plea to mean just that: insanity and legal incapacity. At other times, it might only signify some degree of mental distress. In the cases of Richard Peioun and Maud wife of William Chantour, jurors might believe a self-killer was non compos mentis, but chose instead to declare the case a felony as a punishment to the self-killer or his or her guardians. Such a complex and bewildering methodology reminds us to heed Janet Colaizzi's prudent warning that "no rational method exists to this day to discriminate insanity from crime." 52 In the modern courtroom, pleas of insanity are perhaps best understood in cases where the evidence is unmistakable: delusional or paranoid behavior, morbid impulses, lack of remorse, or at the very least lengthy conversations with colorful characters that do not exist and cannot be seen by anyone else..$^{53}$ Still, it is important to remember that these hallmarks of madness may be modern creations. It is entirely possible that medieval jurors drew upon their own repository of conspicuous behavior, far different from ours, as is suggested for the early modern era. Michael MacDonald has argued that common stereotypes of madness in seventeenth-century England include the inability to name one's mother and father, taking no pleasure in one's spouse or children, failing to acknowledge one's immediate superiors, violent threats against one's parents, and nakedness. ${ }^{54}$ Similar traits of madness may have existed in the medieval era and yet simply are not obvious enough in this grouping of records for historians to discern. There is some indication that medieval Englishmen sometimes thought an attempt on one's life was sufficient evidence in itself of insanity. 55 For example, when Philip Scatheman was arrested for murdering his wife Agnes, the jury defended his legal incompetence by saying that for a long time before and after the incident, he was possessed with fury [furia] and that many times he wished to drown himself and would have had he not been prevented by his neighbors. ${ }^{56}$ Similarly, when Goda wife of John Attebek was indicted for the deaths of her son and daughter, the jurors note at the 
time she was out of her mind [demens] and furious [furiosa], that sometimes she wished to drown herself in ditches filled with water, and she would have had she not been stopped by her neighbors. ${ }^{57}$ Cases of this nature, in which evidence of suicidal impulses seems to be presented with the sole intention of substantiating a non compos mentis plea, make it clear that we still have much to learn about medieval perceptions of homicidal insanity. In the absence of this knowledge, at the very least, Colaizzi's words of caution remind us to be wary of holding medieval jurors to higher standards than our own.

Perhaps even more telling, medieval juries and court scribes frequently seem to have had difficulty drawing the line between suicide and death by misadventure. For example, in some of the coroners' rolls examined, portions of the roll were organized according to the nature of the case: homicides separated from thefts from accidental deaths and so on. ${ }^{58}$ Despite initial expectations that suicides should belong to the category of homicides, it seems clear that suicide did not always fall neatly into this group. In fact, in at least four instances, the records list cases of felonious self-killing among entry after entry of death by misadventure, hinting that jurors may sometimes have understood suicide in this light. ${ }^{59}$ Moreover, there are numerous situations where scribes were at odds over whether a self-killing was in fact a suicide or an accident. For example, when Roger of Garforth of Fairburn of Yorkshire, freely [gratis] drowned himself in the River Aire, the narrative in the eyre roll covering the years 1279-81 records the judgment as being both an accident and a suicide [iudicium infortunium fe de se]. ${ }^{60}$ Similarly, the marginalia of the chaplain John of Stourton's hanging in his home reports that his death was both by misadventure and suicide. ${ }^{61}$ In at least ten other cases, both outcomes are recorded in either the narrative or the marginalia, sometimes with one verdict inscribed on top of the other, but most often with one verdict crossed out and the other written neatly beside it (without compression, as if both were originally included in the text). ${ }^{62}$ Again, it is possible that some of these double-listed verdicts represent scribal errors; however, because of the seriousness of such a decision, it seems likely that court scribes proceeded with caution when dealing with cases of self-killing. While these various examples are not numerous, collectively they suggest at least two possible outcomes: one, that court scribes did not have a clear understanding of the distinction between felonious suicide and self-killing by misadventure; or two, that court scribes and jurors themselves may have perceived some self-killings as a variant of death by misadventure. 


\section{Evidence of compassion}

Where suicide is concerned, the traditional perception is that medieval jurors exhibited great depths of compassion. Although jurors were less compassionate than has been previously imagined, indeed, the coroners' rolls reveal a sense of concern and empathy even for some self-killers. For example, a Cambridgeshire coroner's roll recounts in a sympathetic tone a case from the year 1372 when Ellen wife of Thomas the clerk of Barnwell arose from her bed one night and, dressed only in her underwear [camisia], walked to the river and drowned herself. The record notes, however, that at that time she was out of her senses [extra sensum] because of the great sorrow [magnitudinem predictis doloris] which she held for her son. The inquest jurors report that Ellen owned no lands, goods, or chattels that might be forfeit to the king. The trial jury's verdict recorded in the margin is simply that she drowned herself, but nowhere does the narrative or marginalia declare her a felon. ${ }^{63}$ Ellen's situation was one in which many jurors might find sympathy. With such high mortality rates in this period, one would be hard-pressed to find a juror who had not lost a child through sickness, malnutrition, or misadventure. Whether jurors agreed with Ellen's actions or not, the jury may well have believed that Ellen's husband, having now lost two members of his family, did not deserve to be held responsible financially. Similarly, in May of 1365 Leticia wife of Simon Grindok de Necton walked to a nearby forest, stabbed herself in the belly so that her innermost parts spilled out, causing her to die not long after. The coroner's roll in which this case is found describes her as having suffered from such great sadness that she lacked a sane mind [tanta dolore ... per quod caruit bona memorie]. The record also notes that before she died, she confessed her sin and was contrite, and that she received the last rites. ${ }^{64}$ While the roll fails to identify the source of Leticia's great "sadness," the overall impression rendered by the record is that grief as a motivation for suicide, if not acceptable, was something jurors could understand. The death of Julianne wife of Gilbert Cotene, as reported in a Northamptonshire coroner's roll, is reminiscent of a period romance. When her husband Gilbert died in a fire, Julianne followed her husband to the grave, voluntarily drowning herself in the River Nene. The indictment reports that she has no goods or chattels; nowhere does it state that the jury judged her (admittedly romantic) actions felonious. ${ }^{65}$ All three of these cases challenge long-established historical assumptions about medieval approaches to suicide. Joel Eigen has argued that "what was different [about suicide] in the late eighteenth century appears to have been 
a growing conviction that suicide was an understandable calamity, rooted not in temptation by the devil but in secular trauma, such as disappointed love or financial ruin." 66 Certainly, these accounts would suggest that medieval jurors, much like their more modern counterparts, were not immune to secular trauma. Perhaps, instead, the difference lies in the records themselves. Modern documentary procedure requires a full dictation of the trial. This meticulous approach to record-making is a far cry from that in the Middle Ages. Medieval scribes, at best, summarized the case. Most did not feel inclined to state the obvious, nor were they expected to do so. As long as the scribe accurately detailed the suicide's chattels, as well as the name of the perpetrator and date and location of the crime, he had more than adequately fulfilled his commitment. While some chose to offer a more elaborate narration, historians should greet their work as a windfall and not mistake it for the norm. If more complete records for the period did exist, we might well discover that a sense of compassion was not so exceptional. At the very least, these cases affirm that jurors might empathize with the tragedies and losses that led some individuals to take their own lives.

\section{Suicide and "phrases of afforcement"ss / Journals}

The more common response to suicide by a medieval juror, however, was not compassion, but conviction. Jurors at all levels of medieval society usually chose to describe a self-killing as felonious. In a minority of cases, the phrasing of indictments indicates that jurors could be especially determined to condemn the deceased. For example, a Northampton coroner's roll from the year 1346 recounts the death of Agnes wife of John of Middleton:

It happened at Middleton on the Friday of the feast of Saint Hugh the Bishop in the twentieth year of the reign of King Edward the third after the conquest that a certain Agnes wife of John the smith's son of Middleton was found dead and was viewed by Andrew of Landwhat the coroner ... [the jury] says on its oath that on the Wednesday before the said feast of Saint Hugh the Bishop in the aforementioned year, in the middle of the night, the said Agnes, with malice aforethought, climbed a certain tree outside the home of the said John her husband in Middleton and over a branch of that tree hanged herself with a cord around her neck. And so she feloniously killed herself. ... the men of Middleton have chopped down the tree and the body of Agnes has been buried. ${ }^{67}$ 
This is not a typical case of suicide. In many ways, this account is more reminiscent of a homicide than a felonia de se. The fact that the roll describes Agnes as having "feloniously" [felonice] killed herself is (clearly) not unusual. What is remarkable is that the jury chose to color this report with powerful terms like "by night" [noctanter] and "with malice aforethought [ex malicia precogitata]. John Bellamy has described loaded terms of this nature as "phrases of afforcement," that is, words or phrases deliberately inserted into indictments by coroners' inquest or grand juries in the early part of the process to incline trial juries, which pass final judgment on a case, toward a verdict of guilt. ${ }^{68}$ Jurors usually employed phrases of this nature only in egregious cases of felony, typically crimes of stealth or premeditation. ${ }^{69}$ Bellamy is not the first or the only historian to recognize the value of this kind of language for the purposes of communication between juries. Because trial jurors were rarely drawn from the ranks of those who lived closest to the scene of the crime, historians have recognized the value of phrases of afforcement in determining the final outcome of a case. Without these phrases, a trial jury, composed entirely or in part of strangers, would have been incapable of arriving at a unanimous verdict for a case they probably knew very little about. ${ }^{70}$ The appearance of this kind of judicial table talk in a record of suicide, however, is puzzling. An entry like this in the coroners' rolls had limited value. It acted as an official record of the findings of an inquest jury to explain a death that was indeed felonious, but would not progress any further in the legal system. Since the offender was dead and probably already buried, a trial jury could not pass a meaningful judgment on the deceased. Any record of the death, then, was perfunctory: primarily it served to identify the chattels forfeit to the king. Given the purpose of the record, there was no need for communication between juries. The appearance of these loaded terms, then, seems best explained as a jury appropriating formulaic language to communicate their own sense of values. By employing this set terminology, jurors were capable of expressing their desire to have Agnes condemned as a suicide, in the hopes that a later jury, or royal justice, for that matter, would not overturn the verdict.

Why would an inquest jury have been so determined to secure a felonious verdict in the death of Agnes wife of John? A number of possibilities exist. A past misdeed may have followed Agnes to her death, coloring jurors' perceptions of her and making a verdict of suicide seem particularly appropriate. It is also possible that such a confident judgment was intended to spurn future investigation. If Agnes and her husband had any history of marital spats, the only way for John to escape entirely allegations of wife- 
killing was for the coroner's jury to judge the culpability of the case in an unambiguous manner, laying the blame firmly on the dead. It is perhaps most striking, however, that the different juries involved in this case divided on how to deal with this act. While the original enrollment, as we have seen, places all the blame on Agnes for having plotted her death, a note in the margin describes the death as merely an accident [infortuna].

The phrase "with malice aforethought" (and all its variants) was the standard way for medieval jurors to indicate premeditation, and was the most potent phrase of afforcement. Thus, it is significant that this terminology appears in at least four other cases among the coroners' rolls. In the 1344 death of Maud wife of John Chenyon of Cambridgeshire, the record offers so little detail that it is simply not possible to ferret out the reasoning behind the jury's judgment of premeditated felony [feloniam suam precogitatam]. ${ }^{71}$ In the remaining three cases, however, there is a definite unifying thread. Thomas Hunch, aged fifty years and more, was said to have had a premeditated mind [mente precogitata] when he climbed a ladder in his barn and hanged himself by the neck. William Houdlon, aged forty years and more, allegedly hanged himself with malice aforethought. Also, Thomas Aleyn, aged fifty years and more, stabbed himselfin the stomach out of malice [ex malicia]. ${ }^{72}$ The fact that medieval English society might regard all three of these men as elderly may be the key. ${ }^{73}$ Although tentative, these three cases suggest that medieval Englishmen and women may have frowned upon individuals who chose to escape the rigors of old age by taking their own lives. The inclusion of a phrase of afforcement in the coroner's report, then, discouraged trial jurors, no matter how sympathetic, from simply overturning the original jury's judgment (an action that would have had the perhaps unwelcome repercussions of not only absolving the deceased of his guilt, but also allowing proper burial of the body). The appropriation of such a powerful phrase of afforcement permitted the coroner's inquest jury to take a moral stand on the actions of the deceased.

Although most conspicuous, "with malice aforethought" was not the only phrase of afforcement to appear in royal records of felony indictment for cases of suicide. The coroners' and eyre rolls are littered with a multitude of terms intended to highlight the stealthy and deceitful nature of the crime. Of the 718 cases of suicide, 43 were reported as having been committed by night (noctanter, media nocte, or some other variant of this wording), and another 10 were committed at, or just before, dawn. Only one case notes that the perpetrator murdered [murdravit] herself, ${ }^{74}$ but another 12 emphasize that the act was committed behind closed doors [in domo 
sua clauso hostia] while another three note that the suicide was alone [sola existens] at the time of death. Murray has argued that this "repeated emphasis on privacy ... may have reflected the facts. But that is not why it is there. Jurors wished to make sure no one else was involved." 75 Certainly, these phrases were useful in preventing the wrongful indictment of any alleged accomplices; nevertheless, it seems equally possible that their purpose was to underscore the heinous nature of the crime. As John Bowers has noted, "privacy in the modern sense was a true anomaly in these intimate, granular communities"; consequently, local elites might consider any act hidden from their eyes to be "anti-social," and most likely "sinful or criminal."76 Together, then, jurors phrased at least 10.3 percent of the total number of cases of self-killing in a way intended to secure a final verdict of felonia de se. And it seems clear that trial juries adhered to the findings of the coroner's or grand juries in most of these cases, confirming that phrases of afforcement played an important role in determining the court's perceptions of these self-killings. ${ }^{77}$ At the very least, the significant number of phrases employed confirms that medieval jurors were not generally as compassionate regarding suicide as was once supposed.

An air of antipathy is evident in the unusual nature of at least two cases of suicide appearing in the eyre rolls. A Warwickshire roll from the 1285 eyre recounts how an argument between Walter servant of the earl of Warwick and Hugh of Shropshire quickly turned violent. Walter, who wished to strike the said Hugh [voluit percussisse predictum Hugonem], instead stabbed himself in the belly with a knife, dying immediately. Although the record does note that Hugh was arrested and then acquitted of this death, the jury simultaneously judged Walter's self-killing as felonious. ${ }^{78}$ A Yorkshire eyre roll from only a few years earlier (1279-81) presents an almost identical situation. Robert son of Ralph the spurrier, wishing to kill [volens occidisse] Simon the spurrier, instead killed himself with a knife in the vill of Roderham. The judgment declared, once again, was felonia de se. ${ }^{79}$ To the historian of law, a judgment of felony seems inappropriate at best in both circumstances. The situation described in these records is what Naomi Hurnard has referred to as "killing with transferred intent," an "unintentional killing of one person by a blow deliberately aimed at another," a predicament that justices of the peace generally seemed "happy" to call misadventure. ${ }^{80}$ Moreover, this kind of inflated interpretation, in which a quarrel is effectively turned into a self-slaying, or even "non-slaying" (where the deceased slipped or fell onto the weapon) was a standard formula employed by jurors in order to evade the necessity of a formal pardon. ${ }^{81}$ Why, then, 
were the deaths of Walter and Robert proclaimed suicides? The verdicts on these cases may represent another instance of juridical manipulation in order to uphold the values of the community. The deceased (and their families) would bear the burden of these judgments. Knowing this, jurors may have intended their judgments as punishment for the crime both wished to carry out, but failed.

Historians have long extolled the merits of the non compos mentis plea as an instrument of mercy to be wielded by kind-hearted jurors when determining cases of self-killing. Alexander Murray has argued that, where suicide is concerned, insanity "formed the first flexible element in otherwise rigid principles of judgement." 82 This contention is nurtured by a seemingly capricious medieval jury whose decisions to declare felony in some cases of insanity, and misadventure in others, does not conform to any pattern readily identifiable to the historian. A broader investigation of the records, however, suggests that there may be more to this than meets the eye. Mental defect may not have been a reliable pretext to absolve a suicide's guilt; however, the difficulty experienced by medieval jurors and scribes in simply distinguishing between suicide and death by misadventure indicates that our understanding of the medieval homicidal insanity defense is flawed and requires further investigation. Medieval Englishmen and women had a much different understanding of what distinguished the excusable from the felonious self-killing. Indeed, if inquest and presenting jurors used attempted suicide as evidence of insanity in cases of homicide, it may even have been the case that they believed most suicides were insane,while only some were worthy of impunity.

What these records point to is a highly developed and complex concept of culpability imposed by medieval juries in cases of suicide. In some cases, jurors did not take a hard-line approach to suicide - and may not even have distinguished it, ethically or otherwise, from death by misadventure. In some situations, compassion was warranted. It would seem that suicides motivated by exceptional circumstances for which jurors might find sympathy, such as the loss of a child or a spouse, merited some consideration. More often than not, however, jurors did not feel compelled to excuse a suicide's actions, even if a verdict of suicide might impoverish the surviving family and condemn the dead. Bolstered by contemporary beliefs about suicide found in law, religion, and folklore, jurors appear to have proceeded confidently to judgments of felony. Moreover, it seems possible that jurors employed judgments of suicide as a useful tool to penalize those whose actions were unacceptable to medieval communities. To return once more to the case of 
Richard Peioun that began this discussion, while we will never know the full story behind this toddler's death, the verdict of suicide awarded in this case reminds us that jurors did not passively comply with formal expectations of the law. Their judgments reflect the values of the communities in which they lived, and thus offer a much clearer understanding of popular perceptions and uses of the law.

\section{Notes}

Funding for this research was generously provided by the Social Sciences and Humanities Research Council of Canada. Many thanks also to the participants of the ThirtySeventh International Congress on Medieval Studies at Kalamazoo, Michigan, in 2002 for their comments on a preliminary draft. As well, special thanks go to Cynthia Neville, Krista Kesselring, Tim Stretton, Lawrence Stokes, and Philip Girard for comments and encouragement on a draft of this paper presented at the Graduate-Faculty Seminar Series at Dalhousie University in January 2003. Finally, my gratitude to the anonymous reviewers for this journal for many helpful suggestions. Unless otherwise noted, all translations of legal cases are my own.

1 The National Archives (formerly Public Record Office), London (hereafter TNA), JUST 2/91, m. 7 (Lincs.). (The Public Record office recently officially changed its name to the National Archives.)

2 Henry de Bracton, Bracton: De Legibus et Consuetudinibus Angliae, ed. George Woodbine, trans. Samuel E. Thorne, 4 vols. (Cambridge, Mass.: Belknap Press, 1968) 2:424: "eo quod sensu carent et ratione, non magis quam brutum animal iniuriam facere possunt nec feloniam, cum non multum distent a brutis." Bracton's statements on legal competency laid the base for the "wild beast test" employed at various times throughout history to determine an indicted felon's knowledge of right and wrong. See Daniel N. Robinson, Wild Beasts and Idle Humors: The Insanity Defense from Antiquity to the Present (Cambridge, Mass.: Harvard University Press, 1996), 71-72.

3 Royal and ecclesiastical courts alike did not tend to take accusations of infanticide seriously, most likely because it was a very difficult crime to prove and would have put many women and midwives under scrutiny at the death of every stillborn child (a common occurrence in this period). See R. H. Helmholz, "Infanticide in the Province of Canterbury during the Fifteenth Century," History of Childhood Quarterly 2 (1975): 379-90.

4 Of course, if Richard's father was dead already and he stood to come into his inheritance when he turned of age, his status as a ward might have made his inheritance forfeit to the Crown for a year and a day, as is the case with any other felon. However, the account of his death in the coroner's roll says nothing about chattels or land. Bearing in mind that the coroners' rolls existed expressly for recording what is due to the king, such an omission would have been very unusual indeed. 
5 Carrie Smith, "Medieval Coroners' Rolls: Legal Fiction or Historical Fact?" in Courts, Counties, and the Capital in the Later Middle Ages, ed. Diana E. S. Dunn (New York: Sutton, 1996), 107. While it is still unclear exactly how the medieval English treated their suicides, by the early sixteenth century, English suicides were buried at the crossroads with a stake through the chest, pinning the body to the ground. For a fuller discussion, see Robert Halliday, "Wayside Graves and Crossroads Burials," Proceedings of the Cambridge Antiquarian Society 84 (1996 for 1995): 113-18

6 Helmholz, "Infanticide in the Province of Canterbury," 382-85.

7 Barbara A. Hanawalt, "Narratives of a Nurturing Culture: Parents and Neighbors in Medieval England," in her "Of Good and Ill Repute": Gender and Social Control in Medieval England (Oxford: Oxford University Press, 1998), 174.

8 Rosemary Horrox, "Purgatory, Prayer and Plague: 1150-1380," in Death in England: An Illustrated History, ed. Peter C. Jupp and Clare Gittings (New Brunswick, N.J.: Rutgers University Press, 2000), 98.

9 Georges Minois, History of Suicide: Voluntary Death in Western Culture, trans. Lydia G. Cochrane (Baltimore: Johns Hopkins University Press, 1999), 25; and see Roy Porter, Madness: A Brief History (Oxford: Oxford University Press, 2002), 23.

10 Jean-Claude Schmitt, Ghosts in the Middle Ages: The Living and the Dead in Medieval Society (Chicago: University of Chicago Press, 1998), 6-7. See also Paul Barber, Vampires, Burial, and Death (New Haven, Conn.: Yale University Press, 1988), passim.

11 Thomas Andrew Green, Verdict According to Conscience: Perspectives of the English Criminal Trial Jury, 1200-1800 (Chicago: University of Chicago Press, 1985); J. G. Bellamy, The Criminal Trial in Later Medieval England: Felony before the Courts from Edward I to the Sixteenth Century (Toronto: University of Toronto Press, 1998). Then, as now, there were different forms of juries. The coroner's jury was the first to encounter a case. Composed of people from the vicinity where the crime had taken place, the jurors were asked to pass a preliminary judgment on what had happened, with the expectation that they might have been witnesses to the crime, or at the very least had good knowledge of what had transpired. Cases of felony might also be reported for the first time in the records of grand jurors, representatives from the community assembled by the sheriff, and asked to report on all crimes that had taken place in the community. The next stage was the eyre or assize court, at which the gaols were delivered and trial jurors were asked to pass final sentencing on accused felons. While most historians have focused on the trial jury as the locus for jury nullification, Green's Verdict According to Conscience also comments extensively on the role of the coroner's jury as the first opportunity for manipulation by a jury. For a similar study of the grand jury and its role in jury nullification, see B. W. McLane, "Juror Attitudes towards Local Disorder: The Evidence of the 1328 Lincolnshire Trailbaston Proceedings," in Twelve Good Men and True: The Criminal Trial Jury in England, 1200-1800, ed. J. S. Cockburn and Thomas A. Green (Princeton, N.J.: Princeton University Press, 1988), 36-64.

12 See Christopher Daniel's discussion of the English perspective of purgatory in Death and Burial in Medieval England, 1066-1550 (London: Routledge, 1997), 11-12.

13 Barbara A. Hanawalt, Crime and Conflict in English Communities, 1300-1348 (Cambridge, Mass.: Harvard University Press, 1979), 102. 
14 Michael MacDonald and Terence R. Murphy, Sleepless Souls: Suicide in Early Modern England (Oxford: Clarendon Press, 1990), 16-23.

15 Alexander Murray, Suicide in the Middle Ages, Volume 1: The Violent against Themselves (Oxford: Oxford University Press, 1998), 384-85.

16 Gwen Seabourne and Alice Seabourne, "The Law on Suicide in Medieval England," The Journal of Legal History 21 (2000): 35 (original emphasis) and 30, respectively.

17 A coroner's inquest sometimes served itself as an indictment. Thus, it is possible that a self-killing might have gone no farther than the records of the coroner.

18 For Somerset, Stafford, and Suffolk, it was not easy to find two large eyres with legible rolls in good condition. The following manuscripts were examined TNA JUST 1: Bedfs. (24, 46); Berks. (36, 44); Bucks. (63, 55); Cambs. (86, 95); Cornwall (111, 118); Cumberland (133, 135); Derby (166, 148); Devon (181, 175); Dorset (204, 213); Co. Durham (223); Essex (230, 233, 238, 242, 244, 245); Glos. (278, 274); Hants. (780, 787); Hereford (302, 300C); Herts. (325, 318); Hunts. (345, 343); Kent (369, 374); Lancs. (409); Lancaster (436, 437); Leics. (461, 455); Lincs. (486, 480, 488); Middlesex (486, 538); Norf. (568, 573); Northants. (635, 623); Northumb. (653); Notts. (664, 683); Oxon. (700, 705); Rutland (725); Salop (737, 739); Somerset (759); Staffs (806); Suff. (827); Surrey (876, 872); Warwick (951A, 956); Westmorland (982, 986); Wilts. (996, 1005 pt. 2); Worcs. (1025, 1022); Yorks. (1043, 1051, 1053, 1060, 1070, 1073, 1078, 1098, 1109, 1101, 1108); and the entirety of TNA JUST 2. The following published sources were examined: Helen M. Cam, ed., The Eyre of London 14 Edward II A.D. 1321, Selden Society (hereafter SS) 85 and 86 (1968); Helena M. Chew and Martin Wienbaum, eds., The London Eyre of 1244, London Record Society 6 (1970); M. T. Clanchy, ed., The Roll and Writ File of the Berkshire Eyre of 1248, SS 90 (1973); Anne Reiber DeWindt and Edwin Brezette DeWindt, eds., Royal Justice and the Medieval English Countryside: The Huntingdonshire Eyre of 1286, the Ramsey Abbey Banlieu Court of 1287, and the Assizes of 1287-88, pt. 1 (1981); G. Herbert Fowler, ed., "Roll of the Justices of Eyre at Bedford, 1227," Bedfordshire Historical Record Society 3 (1917); G. Herbert Fowler, ed., "Calendar of the Roll of the Justices on Eyre, 1247," Bedfordshire Historical Record Society 21 (1939); Charles Gross, ed. Select Cases from the Coroners' Rolls, A.D. 1265-1413, with a brief account of the history of the office of coroner, SS 9 (1896); Alan Harding, ed., The Roll of the Shropshire Eyre of 1256, SS 96 (1981); R. F. Hunnisett, ed., Bedfordshire Coroners' Roll, Bedfordshire Historical Record Society 41 (1960); R. F. Hunnisett, ed., Calendar of Nottinghamshire Coroners' Inquests, 14851558, Thoroton Society Record Series 25 (1969); R. F. Hunnisett, ed., Sussex Coroners' Inquests, 1558-1603 (London: TNA, 1996); C. A. F. Meekings, ed., Crown Pleas of the Wiltshire Eyre, 1249, Wiltshire Archaeological and Natural History Society, Records Branch 15 (1961); W. Page, ed., Three Early Assize Rolls for the County of Northumberland, Surtees Society 88 (1891); W. M. Palmer, ed., The Assizes held at Cambridge, A.D. 1260: Being a condensed translation of Assize Roll 82 in the Public Record office, with an introduction (Linton, 1930); J. E. Thorold Rogers, ed., Oxford City Documents: Financial and Judicial, 1268-1665, Oxford Historical Society 18 (1891); Reginald R. Sharpe, ed., Calendar of Coroner's Rolls of the City of London, A.D. 1300-1378 (London, 1913); Doris Mary Stenton, ed., The Earliest Lincolnshire Assize Rolls, A.D. 1202-1209, Lincoln Record Society 22 (1926); Doris Mary Stenton, ed., Rolls of the 
Justices in Eyre, being the Rolls of Pleas and Assizes for Yorkshire in 3 Henry III (121819), SS 56 (1937); Doris Mary Stenton, ed., Pleas Before the King or his Justices, 1198 1210, Vol. II: Rolls or Fragments of Rolls from the Years 1198, 1201 and 1202, SS 67, pt. 2 (1952); Henry Summerson, ed., Crown Pleas of the Devon Eyre of 1238, Devon and Cornwall Record Society, New Series 28 (1985); Martin Weinbaum, ed., The London Eyre of 1276, London Record Society 12 (1976); Woodbine, ed., and Thorne, trans., Bracton.

19 For the purposes of statistical analysis, I have attempted to identify all cases that appear in more than one record and thus should only count as a single case of selfkilling. The figure of 718 cases, then, does not reflect the number of times self-killings appear in these records, but rather the number of cases (that may or may not appear more than once). Some of these cases have appeared also in the works of Seabourne and Seabourne, "The Law on Suicide"; and Murray, Suicide in the Middle Ages.

20 The geographical spread of suicides is the subject of my next study, "Local Values, Local Concerns: Suicide and the Jury in Medieval England."

21 MacDonald and Murphy, Sleepless Souls, 22.

22 This figure does not include those cases where the narrative describes the act as deliberate, but fails to employ the actual terms felonice or felonia.

23 MacDonald and Murphy, Sleepless Souls, 23.

24 A person of unknown gender committed one case. Unfortunately, the perpetrator's name was torn off and the manuscript is in poor condition. See TNA JUST 1/1078, m. 45 (Yorks.), death of of Ravensowrth in Ainderby.

25 Hanawalt, Crime and Conflict, 115.

26 H. C. Erik Midelfort, A History of Madness in Sixteenth-Century Germany (Stanford, Calif.: Stanford University Press, 1999), 190.

27 Because most sources addressing this issue date to the thirteenth century or earlier, it is always possible that these perceptions simply do not reflect later medieval opinions on the matter of suicide and insanity. However, it is worthy of note that thirteenthcentury jurors do not appear to differ dramatically from fourteenth-century jurors in their rate of convictions relating to madmen. Thirteenth-century jurors convicted 16 of 47 madmen ( 34 percent); fourteenth-century jurors convicted 24 of 56 madmen ( 42 percent). Thus, it seems more likely that a gap between the theory and the practice of the law, and not change in belief over time, best explains this divergence.

28 TNA JUST 1/573, m. 95 (Norf.).

29 TNA JUST 1/547A, as translated in Helen M. Cam, ed., The Eyre of London, 14 Edward II, A.D. 1321, Selden Society 85 (London: Quaritch, 1968), 93.

30 Bracton, 2:424: "Et de mente capto, et de frenetico, vel de infantulo?"

31 TNA JUST 2/191, m. 6d (Cambs.).

32 TNA JUST $1 / 55$, m. 20 (Bucks.).

33 TNA JUST 1/351A, m. 7d (shire?), as discussed by Anne Reiber DeWindt and Edwin Brezette DeWindt, eds., Royal Justice and the Medieval English Countryside: The Huntingdonshire Eyre of 1286, the Ramsey Abbey Banlieu Court of 1287, and the Assizes of 1287-88, 2 vols. (Toronto: Pontifical Institute of Mediaeval Studies, 1981), 1:52.

34 TNA JUST 1/653/11/1 (Northumb.).

35 See, for example, TNA JUST 2/6, m. 2 (Beds.), death of Emma le Bere; JUST 2/57, 
m. 14 (Glos.), death of Alice Gelle of Milton; or JUST 2/215, m. 5 (Yorks.), death of John of Appleton. The coroners' rolls report all of these suicides as possessing no goods or chattels at the time of their deaths. The role played by coroners and royal justices, however, should not be dismissed entirely with this finding. Even if financial concerns were not the prime motivator, it seems clear that it was not always easy for juries to distinguish a suicide from death by misadventure. The more learned backgrounds and greater experience of royal officials might have informed the decisions of jurors in some cases of misadventure due to insanity, although the records impede any insight into this process.

36 Seabourne and Seabourne, "The Law on Suicide," 30.

37 Bracton, Bracton: De Legibus et Consuetudinibus Angliae, 4:177.

38 Francis M. Nichols, ed. and trans., Britton, 2 vols. (Oxford, 1865), 2.3.7; Henry G. Richardson and George O. Sayles, ed. and trans., Fleta, Selden Society 72, 79, 99 (London: Quaritch, 1955, 1972, 1984), II.1.37.

39 Wendy J. Turner, “Afflicted with Insanity': The Care and Custody of the Feeble Minded in Late Medieval England," (Ph.D. diss., University of California, Los Angeles, 2000), 129.

40 Porter, Madness, 45-47, 42.

41 Turner, “Afflicted with Insanity,” 17.

42 Ibid., 17-18, 205-17.

43 Ibid., 11. Francis Henry Stratmann, A Middle English Dictionary (Oxford, 1891), 692, notes that wode means "mad" or "furious." See TNA JUST 1/238, m. 48d (Essex); JUST 1/461/34 (Leices.).

44 TNA JUST 2/221, m. 3 (Yorks.).

45 TNA JUST 2/67, m. 28 (Lincs.).

46 TNA JUST 1/996, m. 27 (Wilts.).

47 TNA JUST 2/155, m. 6 (Southants.).

48 TNA JUST 2/155, m. 7 (Southants.).

49 Minois, History of Suicide, 30.

50 Green, Verdict According to Conscience, 28-64.

51 Trevor Dean, Crime in Medieval Europe, 1200-1500 (Edinburgh: Pearson Education, 2001), 13. See also McLane, "Juror Attitudes," 57; Frederick Pollock and Frederic William Maitland, History of the English Law before the Time of Edward I, 2nd ed., 2 vols. (London, Cambridge University Press, 1968), 2:655: "Trial by jury must have been in the main trial by general repute."

52 Janet Colaizzi, Homicidal Insanity, 1800-1985 (Tuscaloosa: University of Alabama Press, 1989), 6.

53 For a discussion of qualities psychiatrists have associated with homicidal insanity, see Colaizzi, Homicidal Insanity, 7.

54 See Michael MacDonald, Mystical Bedlam: Madness, Anxiety, and Healing in Seventeenth-Century England (Cambridge, Mass.: Cambridge University Press, 1981), 113-39.

55 Cases examined in Hanawalt's work on crime in East Anglia first brought this to my attention. See Hanawalt, Crime and Conflict, 102.

56 TNA JUST 3/48, m. 20 (Northants). 
57 TNA JUST 3/125, m. 10 (Northants). The Northamptonshire gaol delivery rolls boast at least two other cases of this nature. See TNA JUST 3/48, m. 22d; and JUST 3/119, m. $14 \mathrm{~d}$.

58 Sorting cases by the nature of the crime may not have been very unusual. Both Thomas Green and Bernard McLane have observed the existence of a pre-inquest sorting process between felony and trespass, especially where theft is concerned, in a variety of royal records. See Green, Verdict According to Conscience, 61; McLane, "Juror Attitudes," 53.

59 All of the following cases are suicides reported in the midst of case after case of accidental deaths: TNA JUST 2/18, m. 11d (Cambs.), death of Thomas Hunch; JUST 2/67, m. 23 (Lincs.), death of Agnes of Gayton; JUST 2/85, m. 8 (Lincs.), Christina who was the wife of Roger Walker of Manthorp near Grantham; JUST 2/91, m. 5 (Lincs.), death of William son of John of Burtof.

60 TNA JUST 1/1101, m. 67 (Yorks.), death of Roger of Garforth of Fairburn.

61 TNA JUST $1 / 213, \mathrm{~m} .32 \mathrm{~d}$ (Dorset).

62 TNA JUST 1/242, m. 104 (Essex), death of Richard Chaplain of Chelmersford; JUST 1/230, m. 6 (Essex), death of Katherine former wife of Hugh of Latton; JUST 1/488, m. 9 (Lincs.), death of Ellen daughter of John Lewyn; JUST 1/488, m. 20d (Lincs.), death of Maud Bedding of Belleton; JUST 1/568, m. 30 (Norf.), death of Stephen Red; JUST 1/739, m. 64 (Salop.), death of Richard son of Richard Hervy; JUST 1/759, m. 40d (Somerset), death of Richard Cosin; JUST 1/876, m. 48 (Suff.), death of Alice of Thome (Thorns?); JUST 1/982, m.29d (Westmorland), death of Richard of Kirkby; and JUST 2/215, m. 38 (Yorks.), death of Walter Greg of Darrington.

63 TNA JUST 2/23, m. 3 (Cambs.).

64 TNA JUST 2/104, m. 44 (Norf.).

65 TNA JUST 2/111, m. 15d (Northants.).

66 Joel Peter Eigen, Witnessing Insanity: Madness and Mad-Doctors in the English Court (New Haven, Conn.: Yale University Press, 1995), 17.

67 TNA JUST 2/113, m. 6. (Northants.).

68 Bellamy, The Criminal Trial, 29

69 J. M. Kaye carefully noted that the term malice aforethought (ex malicia precogitata) did not imply premeditation as it does today; rather it included "killings by secrecy or stealth, killing from ambush, and . . . all other killings which gave rise to no recognised defence." See J. M. Kaye, "The Early History of Murder and Manslaughter," Law Quarterly Review 82 (1967): 365-95, 569-601, at 378. Nevertheless, more recent research has demonstrated that, while stealthy crimes were held in little regard by medieval Englishmen and that these crimes stood out in indictments with the use of terms like noctanter, the phrase ex malicia precogitata was usually employed to suggest true premeditation. See Green, Verdict According to Conscience, 53-59; and also Thomas Andrew Green, "The Jury and the English Law of Homicide, 1200-1600," Michigan Law Review 74 (1976): 462-69. See also Bellamy, The Criminal Trial, 61-63.

70 For a discussion of the "self-informing" nature of the jury, see B. W. McLane, "Jurror Attitudes towards Local Disorder: The Evidence of the 1328 Trailbaston Proceedings"; J. B. Post, "Jury Lists and Juries in the Late Fourteenth Century," both in 
Green and Cockburn, Twelve Good Men and True, 33-64 and 65-67. See also Green's response to these articles in the same volume, entitled "A Retrospective on the Criminal Trial Jury, 1200-1800," 358-99. Additionally, see Daniel Klerman, "Was the Jury Ever Self-Informing?" in Judicial Tribunals in England and Europe, 1200-1700, vol. 1, ed. Maureen Mulholand and Brian Pullen (Manchester: Manchester University Press, 2003), 58-80.

71 TNA JUST 2/18, m. 4d (Cambs.).

72 TNA JUST 2/18, m. 11d (Cambs.); TNA JUST 2/18, m. 52 (Cambs.); TNA JUST 2/178, m. 3d (Suff.).

73 It is important to note that coroners' scribes very rarely noted the age of the deceased (the obvious exception to this rule being the deaths of children, whose ages were regularly recorded), and thus it is difficult to determine whether these three were typical or atypical cases of suicide.

74 TNA KB/9/452, m. 97 (Notts.), death of Ellen wife of Robert Grenewod of Mansfield Woodhouse.

75 Murray, Suicide in the Middle Ages, 151.

76 John M. Bowers, "Ordeals, Privacy, and the Lais of Marie de France," Journal of Medieval and Renaissance Studies 24 (1994): 1.

77 The marginalia of 47 out of 74 cases including phrases of afforcement (thus, 64 percent) suggest that trial jurors handed down a final verdict of felonia de se. However, note that many rolls, for one reason or another, do not have verdicts written in the margins; therefore, we cannot assume that the other 36 percent had their verdicts overturned. Jurors may also have declared them felonious.

78 TNA JUST 1/956, m. 41 (Warwick).

79 TNA JUST 1/1101, m. 27 (Yorks.).

80 Naomi D. Hurnard, The King's Pardon for Homicide before A.D. 1307 (Oxford: Clarendon Press, 1969), 98.

81 Green does note, however, that a sixteenth-century treatise classified this kind of case as a suicide, suggesting that at some point in time a transformation took place in the way royal justices interpreted quarrel-induced self-killings. Green, Verdict According to Conscience, 92.

82 Murray, Suicide in the Middle Ages, 171. 